\title{
PENINGKATAN KAPASITAS PRODUKSI PANGAN OLAHAN PADA KELOMPOK USAHA PRODUKTIF DI KECAMATAN SRENGAT, KABUPATEN BLITAR
}

\author{
Increasing Food Production Capacity at Productive Business Group \\ at Srengat Sub-Distric, Blitar Regency
}

\author{
Panji Deoranto dan Retno Astuti \\ Jurusan Teknologi Industri Pertanian, Fakultas Teknologi Pertanian, Universitas Brawijaya, Jl. \\ Veteran, Malang
}

\begin{abstract}
In Srengat sub-district, Blitar regency, there are several productive businesses that process food such as madumongso, sambel pecel, dumpling chips, yuyu cake, stick, and sponge cakes and cakes produced by Mekar Jaya Women Farmer Group (KWT) and Small and Medium Enterprise (SME) Ananda. The problem faced by KWT Mekar Jaya is the milling of spices and nuts in the production of sambel pecel because this KWT does not have equipment for grinding. Milling is done in the market, so it is inefficient. Another problem is the formation of dough sheets in the production of keripik pangsit that are still manual, therefore it takes a long time. KWT Mekar Jaya also still packs using candles that make the risk of imperfect packaging. Problems in the food processing in SME Ananda is limited capacity due to simple equipment used, household scale, and low capacity. The critical point of production capacity is in the process of mixing the dough and baking. Both have been using a small mixer and a small oven. Another problem is the packaging process that often fails because the hand sealer is not working properly. This program aims to increase the production capacity of food production in KWT Mekar Jaya and SME Ananda. The program to increase production capacity and processed product quality in KWT Mekar Jaya is done through facilitation of production equipment of sambel pecel and keripik pangsit in the form of grinder and sheeter. Improvement of packaging quality is done through facilitation of hand sealer and improvement of label design. The program to increase production capacity and quality of SME Ananda is done through increasing the capacity of baking, mixing, and improvement of packaging. Improvement of packaging label is done for keripik pangsit, sambel pecel, and madumongso with facilitation pedal sealer. Through equipment fasilitation, both partners can increase the capacity and efficiency of production. Partners have also diversified their processed products using facilities from this IbM program.
\end{abstract}

Keywords: baking, critical point, packaging, production capacity

\begin{abstract}
ABSTRAK
Di Kecamatan Srengat, Kabupaten Blitar, terdapat beberapa usaha produktif yang mengolah pangan seperti madumongso, sambel pecel, keripik pangsit, kue untruk yuyu, stick, dan kue bolu serta cake yang diproduksi Kelompok Wanita Tani (KWT) Mekar Jaya dan Usaha Kecil Menengah (UKM) Ananda. Permasalahan yang dihadapi oleh KWT Mekar Jaya adalah penggilingan bumbu dan kacang pada produksi sambel pecel tidak bisa dikerjakan sendiri karena tidak mempunyai alat mekanis. Penggilingan dilakukan di pasar sehingga tidak efisien. Permasalahan lain adalah pembentukan lembaran adonan pada proses produksi keripik pangsit yang masih manual sehingga membutuhkan waktu lama. Mitra juga masih mengemas menggunakan lilin sehingga beresiko pengemasan tidak sempurna. Permasalahan pada proses produksi olahan pangan di UKM Ananda adalah keterbatasan kapasitas akibat peralatan yang digunakan masih sederhana, skala rumah tangga dan kapasitas kecil. Titik kritis peningkatan kapasitas adalah pada proses pengadukan adonan dan pemanggangan. Keduanya selama ini
\end{abstract}


menggunakan mixer kecil dan oven kecil. Permasalahan lain adalah proses pengemasan yang sering gagal karena alat hand sealer yang sudah tidak berfungsi dengan baik. Program ini bertujuan meningkatkan kapasitas produksi olahan pangan di KWT Mekar Jaya dan UKM Ananda. Program peningkatan kapasitas produksi dan mutu produk olahan di KWT Mekar Jaya dilakukan melalui fasilitasi peralatan produksi sambel pecel dan keripik pangsit berupa penggiling bumbu pecel dan pencetak lembaran adonan (sheeter). Perbaikan kualitas kemasan dilakukan melalui fasilitasi hand sealer dan perbaikan desain label kemasan. Program peningkatan kapasitas produksi dan mutu olahan UKM Ananda dilakukan melalui peningkatan kapasitas pemanggangan, pengadonan, dan perbaikan proses pengemasan. Perbaikan label kemasan akan dilakukan untuk kemasan keripik pangsit, sambel pecel, dan madumongso dengan fasilitasi alat pedal sealer. Dengan adanya fasilitasi peralatan ini, kedua mitra dapat meningkatkan kapasitas dan efisiensi produksi. Mitra juga telah melakukan diversifikasi produk olahannya mengguankan fasilitas peralatan dari program IbM ini.

Kata kunci: kapasitas produksi, pemanggangan, pengemasan, titik kritis

\section{PENDAHULUAN}

Olahan hasil pertanian dan kehutanan merupakan usaha yang banyak digeluti oleh masyarakat Blitar dalam bentuk industri kecil yang mencapai $99,64 \%$. Pada tahun 2016 tercatat terdapat 1210 usaha kecil menengah (UKM) dan industri rumah tangga (IRT) yang mengolah hasil pertanian (Pemerintah Kabupaten Blitar, 2016). Usaha tersebut sebagain besar dalam bentuk usaha pangan olahan yang dilakukan secara berkelompok dan ada yang bersifat individual. Adapun jangkauan pemasaran hasil industri kecil tersebut sebagian besar untuk memenuhi kebutuhan pangsa pasar lokal dan regional dan sedikit ekspor.

Usaha olahan pangan yang dilakukan secara berkelompok umumnya bergabung dalam Koperasi Wanita (Kopwan) atau Kelompok Wanita Tani (KWT). Dorongan pemerintah daerah yang intensif bagi masyarakat untuk secara produktif memberikan nilai tambah bagi hasil pertanian di Kabupaten Blitar telah mendorong kelompok-kelompok wanita baik yang tergabung dengan KWT maupun koperasi wanita melakukan usaha produktif termasuk olahan pangan.

Di Kecamatan Srengat, Kabupaten Blitar, terdapat beberapa usaha produktif yang mengolah pangan seperti madumongso, sambel pecel, keripik pangsit, kue untruk yuyu, stick, dan kue bolu serta cake. Sambel pecel merupakan produk unggulan Kabupaten Blitar (Fuadati, 2008). Madumongso berpotensi sebagai pembawa bakteri asam laktat yang berpotensi sebagai probiotik (Fajriutami, 2005)..Salah satu KWT yang memproduksi pangan olahan di Kecamatan Srengat adalah KWT Mekar Jaya yang diketuai oleh Ibu Mubayanah. Produk olahan KWT ini adalah madumongso, keripik pangsit, dan sambel pecel. KWT ini beranggota 6 orang dari Desa Purwokerto dan baru berdiri pada tahun 2015. Usaha yang dilakukan KWT Mekar Jaya masih sangat sederhana dengan segala keterbatasan tetapi mempunyai semangat yang tinggi untuk berkontribusi terhadap pergerakan ekonomi mikro. Produk olahan pangan yang dihasilkan ditujukan untuk pasar lokal di sekitar Kecamatan Srengat. Walaupun demikian, produk yang dihasilkan bersifat unik dan khas sehingga mempunyai peluang yang besar untuk berkembang. Peran pemerintah dalam pengembangan usaha ini antara lain dalam bentuk pembinaan dan penyuluhan yang dilakukan oleh berbagai dinas seperti Dinas Koperasi dan UMKM, Dinas Perindustrian dan Perdagangan, serta Dinas Kesehatan di Kabupaten Blitar.

Produktivitas KWT Mekar Jaya yang rendah dalam menghasilkan olahan pangan antara lain disebakan keterbatas peralatan yang dimiliki. Mitra memproduksi produk olahan pangan dengan menggunakan peralatan skala rumah tangga. Pengem- 
bangan KWT Mekar Jaya ini diperlukan untuk meningkatkan pendapatan mitra para anggota KWT dan memberikan efek ganda. Peningkatan kapasitas produksi mitra akan meningkatkan kebutuhan akan tenaga kerja sehingga dapat menyerap tenaga kerja wanita yang lain. Selain itu, produksi yang tinggi juga akan mendorong pemasaran produk yang akan menyerap tenaga kerja di bagian pemasaran. Keinginan kuat dari mitra ini yang mendorong pengajuan program IbM ini. Modal motivasi yang kuat dan kemauan untuk bekerja serta keuletan dan ketekunan akan berdampak pada peningkatan kemajuan usaha mitra dengan didukung oleh Program IbM.

Permasalahan yang dihadapi oleh KWT Mekar Jaya adalah penggilingan bumbu dan kacang pada produksi sambel pecel tidak bisa dikerjakan sendiri karena tidak mempunyai alat mekanis. Penggilingan dilakukan di pasar sehingga tidak efisien. Permasalahan lain adalah pembentukan lembaran adonan pada proses produksi keripik pangsit yang masih manual sehingga membutuhkan waktu lama. Mitra juga masih mengemas menggunakan lilin sehingga beresiko pengemasan tidak sempurna.

Usaha olahan pangan lain yang terdapat di Kecamatan Srengat, Blitar, adalah UKM Ananda yang memproduksi kue untruk yuyu, stick, kue bolu, dan cake. Permasalahan pada proses produksi olahan pangan di UKM Ananda adalah keterbatasan kapasitas akibat peralatan yang digunakan masih sederhana, skala rumah tangga dan kapasitas kecil. Titik kritis peningkatan kapasitas adalah pada proses pengadukan adonan dan pemanggangan. Keduanya selama ini menggunakan mixer kecil dan oven kecil. Permasalahan lain adalah proses pengemasan yang sering gagal karena alat hand sealer yang sudah tidak berfungsi dengan baik.

Oleh karena itu, program ini bertujuan meningkatkan kapasitas produksi olahan pangan di KWT Mekar Jaya dan UKM Ananda.

\section{METODE PELAKSANAAN}

Pelaksanaan kegiatan IbM ini ditujukan untuk menyelesaikan permasalahan yang dihadapi oleh kedua mitra KWT Mekar Jaya dan UKM Ananda. Metode pelaksanaannya adalah sebagai berikut:

\section{Peningkatan kapasitas produksi dan mutu olahan pangan Mitra 1 KWT Mekar Jaya}

Berdasarkan hasil diskusi dengan mitra, mitra mengharapkan ada peningkatan kapasitas produksi dan pembinaan untuk meningkatkan kualitas produknya. Pengetahuan mitra yang terbatas serta keterbatasan modal merupakan kendala utama dalam pengembangan usahanya.

Pada proses produksi keripik pangsit adonan yang sudah kalis dicetak berbentuk lembaran (sheeting) menggunakan penggilingan cistik skala rumah tangga. Untuk 3 $\mathrm{kg}$ terigu diperlukan waktu pengilingan sekitar 2 jam. Selanjutnya lembaran adonan dipotong-potong ukuran $2 \times 1 \mathrm{~cm}$. Proses pemotongan ini membutuhkan waktu 1 jam. Untuk meningkatkan kapasitas pencetakan keripik pangsit, diperlukan mekanisasi proses sheeting.

Pengemasan keripik pangsit dilakukan dengan menggunakan api dari lilin sebagai perekat plastik. Akibatnya proses pengemasan tidak konsisten dan seringkali kemasan terbuka. Penggunaan hand sealer dapat meningkatkan konsistensi mutu pengemasan.

Permasalahan pada proses pengolahan sambel pecel di mitra KWT Mekar Jaya adalah mitra tidak mempunyai penggilingan kacang sehingga proses penggilingan dilakukan di pasar. Masalah pada proses penggilingan ini merupakan masalah utama yang dihadapi mitra pada proses produksi sambel pecel. Penggiling kacang dibutuhkan mitra untuk mengatasi permasalahan ini. 
Peningkatan kapasitas produksi dan mutu olahan pangan Mitra 2 UKM Ananda

Mitra 2 UKM Ananda mempunyai permasalahan dalam produksi produk olahannya. Permasalahan pada proses pengolahan kue untruk yuyu, kue bolu, dan cake adalah kapasitas pengadukan adonan yang rendah akibat menggunakan hand mixer. Peningkatan kapasitas pengadonan dapat dilakukan dengan menggunakan mixer tipe planetary.

Permasalahan yang dihadapi mitra pada proses produksi kue bolu dan cake adalah kapasitas pemanggangan yang rendah akibat penggunaan oven kecil skala rumah tangga. Peningkatan kapasitas pemanggangan dapat dilakukan dengan menggunakan oven gas 2 tingkat.

Permasalahan lain yang dihadapi oleh Mitra 2 UKM Ananda adalah proses pencetakan stick yang menggunakan mesin cistik skala kecil dan manual. Pencetakan stick memerlukan untuk $5 \mathrm{~kg}$ bahan memerlukan waktu 3 jam. Peningkatan kapasitas pencetakan stick dapat dilakukan dengan menggunakan pencetak stick mekanis.

\section{HASIL DAN PEMBAHASAN}

Peningkatan kapasitas produksi dan mutu olahan pangan Mitra 1 KWT Mekar Jaya

Koordinasi pelaksanaan IbM dilakukan dengan Mitra 1 KWT Mekar Jaya untuk melihat perkembangan yang terjadi selama satu tahun masa pengajuan proposal. Mitra 1 tetap memproduksi keripik pangsit dan sambel pecel. Produk-produk yang diproduksi Mitra 1 KWT Mekar Jaya dapat dilihat pada Gambar 1.

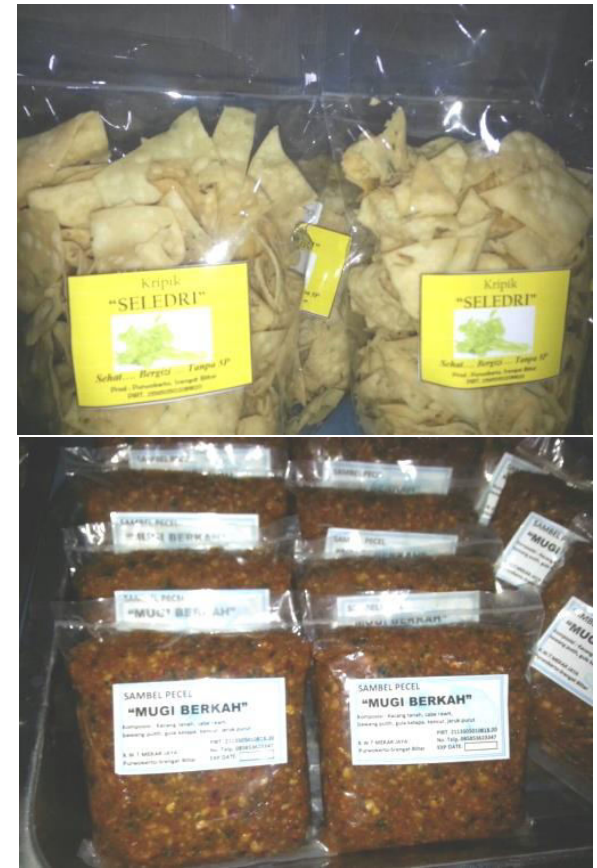

Gambar 1. Produk-produk Mitra 1 KWT Mekar Jaya

Kendala proses produksi keripik pangsit oleh Mitra 1 adalah proses pencetakan lembaran (sheeting) menggunakan penggilingan cistik skala rumah tangga. Mitra 1 memerlukan pencetak lembaran (sheeter) mekanis menggunakan tenaga listrik. Fasilitasi sheeter diberikan kepada mitra dengan Mesin sheeter dengan spesifikasi alat ditunjukkan Gambar 2. Dengan menggunakan alat ini, mitra dapat mempercepat proses produksinya. Alat ini mempunyai kapasitas $20 \mathrm{~kg}$ adonan per jam sehingga waktu produksi mitra dipersingkat yang asalnya 3 jam untuk setiap $10 \mathrm{~kg}$ adonan menjadi 0,5 jam. Dengan alat ini juga mitra telah melakukan diversifikasi produknya yaitu aneka varian keripik pangsit, sepertio keripik seledri, keripik seledri pedas dan lainnya. Alat ini digerakkan dengan menggunakan listrik sehingga menghemat tenaga. Alat ini juga dilengkapi dengan pencetak mie sehingga mitra dapat mengembangkan produknya atau membuat produk olahan yang dipotomng menyerupai mie. 


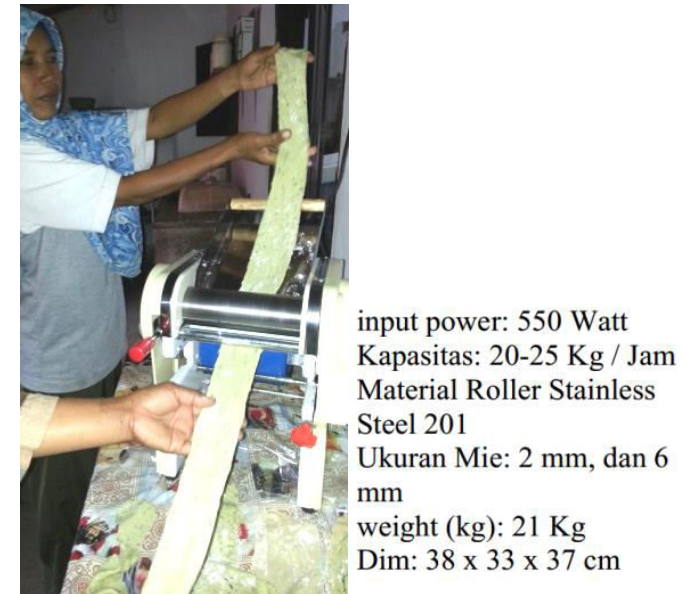

Gambar 2. Sheeter untuk pencetakan keripik pangsit dan spesifikasinya

Perbaikan kualitas kemasan dilakukan dengan meningkatkan proses pengemasan dari menggunakan lilin menjadi menggunakan hand sealer seperti Gambar 18a. Penggunaan hand sealer dapat meningkatkan konsistensi mutu pengemasan karena kemasan lebih rapat dan lebih baik dibandingkan menggunakan lilin. Saat ini mitra sudah mendapat fasilitasi hand sealer dengan hasil penggunaan handsealer dapat dilihat pada Gambar 3.

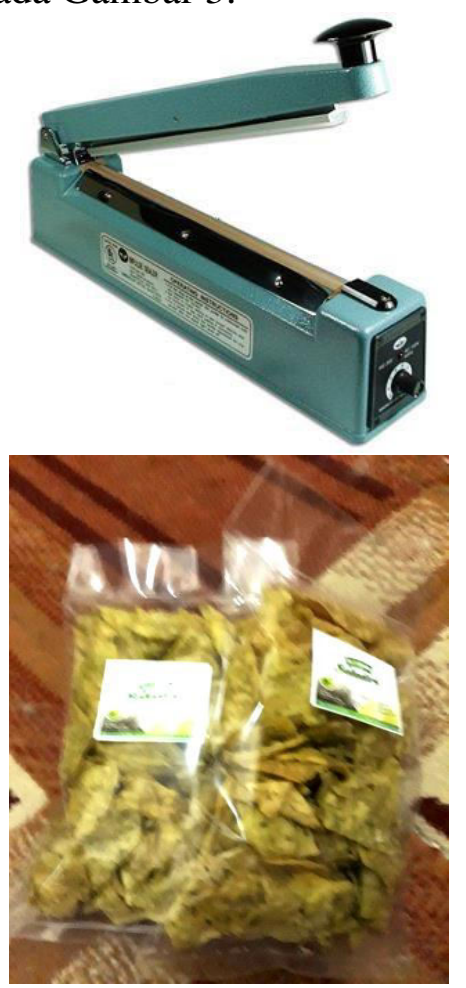

(a)

(b)

Gambar 3. Hand sealer (a) dan kemasan hasil hand sealer (b)
Melalui program ini Mitra 1 dibantu dalam meningkatkan efisiensi proses penggilingan kacang tanah dan bumbu pada proses pembuatan sambel pecel. Peningkatan efisiensi dilakukan dengan fasilitasi mesin penghalus sambel pecel seperti ditunjukkan Gambar 19a. Mesin tersebut sudah diterima dan digunakan oleh mitra. Sebelum pelaksanaan program, mitra menggiling kacang dan bumbu ke pasar yang jaraknya $5 \mathrm{~km}$ dari tempat mitra. Akibatnya proses menjadi tidak efisien. Adanya alat ini dengan kapasitas $20 \mathrm{~kg} / \mathrm{jam}$ sangat membantu mitra untuk meningkatkan kapasitas dan efisiensi produksinya. Bumbu pecel yang telah diolah menggunakan penggiling ini dapat dilihat pada Gambar 4.

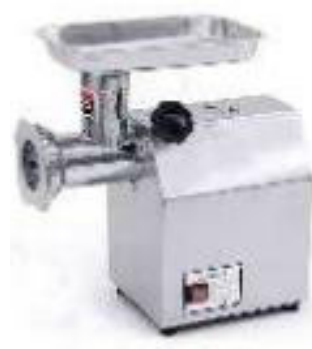

Kapasitas : $20 \mathrm{~kg} / \mathrm{jam}$

(a)

Dimensi : $39.5 \times 24.5 \times 38.5 \mathrm{~cm}$ Daya : $370 \mathrm{~W}$

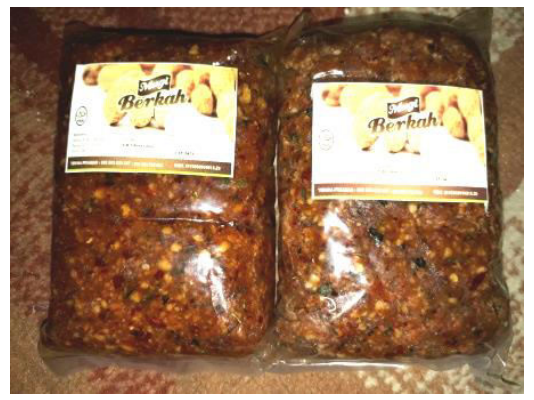

(b)

Gambar 4. Mesin penggiling bumbu pecel dan spesifikasinya (a) dan hasilnya (b)

Peningkatan kapasitas produksi dan mutu olahan pangan Mitra 2 UKM Ananda

Mitra UKM Ananda mempunyai permasalahan dalam produksi produk olahannya. Permasalahan pada proses pengolahan kue untruk yuyu, kue bolu, dan cake adalah kapasitas pengadukan adonan yang rendah akibat menggunakan hand mixer. 
Pada awalnya, peningkatan kapasitas pengadonan akan dilakukan dengan menggunakan mixer tipe satelit. Akan tetapi karena produktif dalam memproduksi produk bakery sehingga jenis mixer yang sesuai untuk mitra adalah mixer tipe planetary. Planetary mixer ini multifungsi karena dapat digunakan untuk adonan cair (batter) seperti untuk untruk yuyu, cake, kue bolu. Juga dapat digunakan untuk adonan kalis (dough) seperti untuk roti dan kue kering. Planetary mixer tersebut sudah diterima dan digunakan mitra untuk produksi produk olahannya seperti ditunjukkan Gambar 5. Mixer ini dilengkapi dengan 3 blade yaitu untuk krim, adonan cair, dan adonan kalis seperti mie dan roti. Adanya berbagai jenis pengaduk ini memungkinkan mitra untuk mengembangkan berbagai produk olahannya.

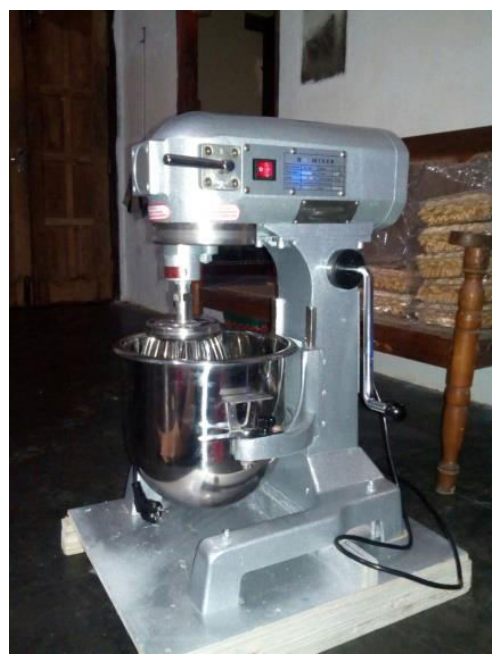

Type : CS-B7

Dimensi : 40 × 25 x $41 \mathrm{~cm}$

Volume Bowl : $7 \mathrm{~L}$

Dough Mixing : $0.5 \mathrm{~kg}$

Cream mixing : $0.75-1 \mathrm{~kg}$

Kapasitas Adonan : $1.5 \mathrm{~kg}$

Listrik : 300 watt, $220 \mathrm{~V} / 1 \mathrm{P}$

Mixing speed : 0 - $280 \mathrm{rpm}$

Gambar 5. Planetary mixer

Permasalahan lain yang dihadapi Mitra 2 pada proses produksi kue bolu dan cake adalah kapasitas pemanggangan yang rendah akibat penggunaan oven kecil skala rumah tangga sebelum program seperti ditunjukkan Gambar 6a. Peningkatan kapasitas pemanggangan dapat dilakukan dengan menggunakan oven gas 2 tingkat seperti dapat dilihat pada Gambar $6 b$.

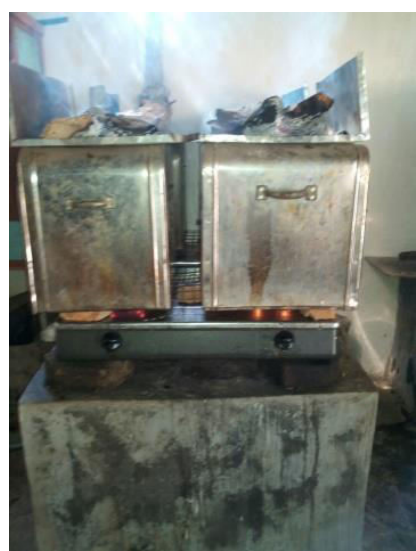

(a)

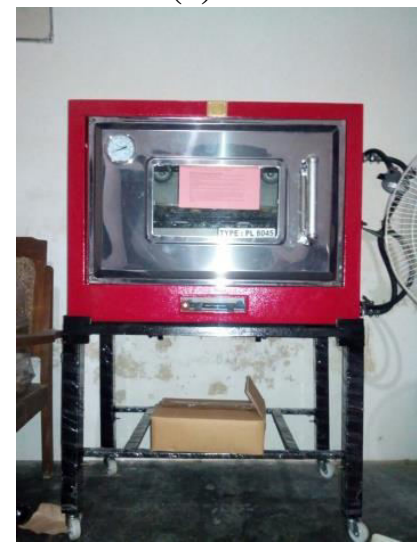

(b)

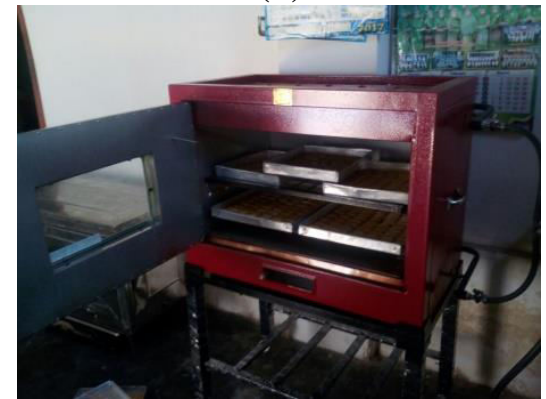

(c)

Gambar 6. Oven sebelum program (a) dan oven gas 2 tingkat dengan api atas dan bawah sesudah program (b)

Dengan menggunakan oven ini, mitra UKM Ananda dapat memproduksi cake dan produk olahan bakery lainnya lebih cepat dan efisien. Penggunaan api atas dan api bawah menyebabkan hasil pemanggangan lebih merata. Selain itu, lubang gas pada oven ini merata di seluruh bagian sehingga hasil pemanggangan menjadi merata dan baik. Dengan menggunakan oven ini, mitra 
telah melakukan diversifikasi produk antara lain produk kue kering cup cake labu kuning seperti ditunjukkan Gambar 7.

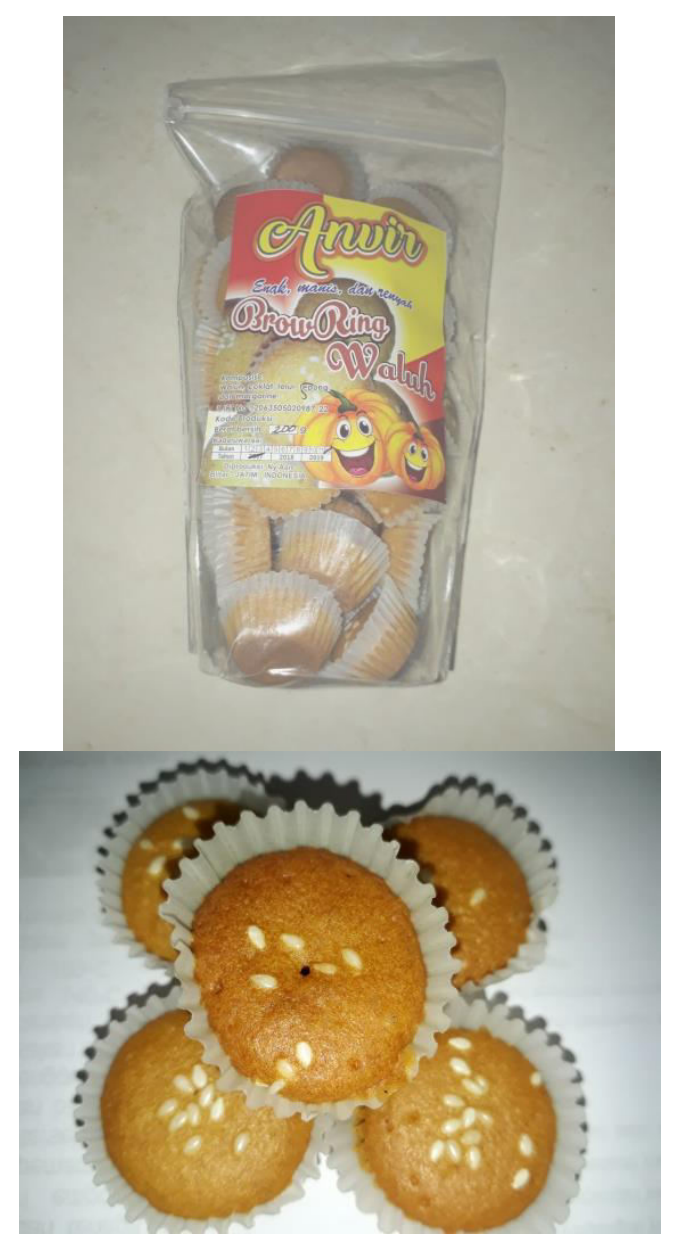

Gambar 7. Diversifikasi produk cup cake kering labu kuning

Permasalahan lain yang dihadapi oleh Mitra 2 UKM Ananda adalah proses pengemasan yang menggunakan hand sealer sehingga tidak sesuai digunakan untuk kemasan mika yang biasa dipakai untyuk kue bolu. Pengemas juga diperlukan untuk produk lain yang saat ini dibuat mitra yaitu keripik pare. Dari hasil diskusi dengan mitra, mitra membutuhkan mesin pengemas. Mitra telah mempunyai hand sealer tetapi dengan kualitas rendah sehingga seringkali rusak dan kurang panas. Pengemasan yang tidak sempurna menyebabkan kemasan produk menjadi tidak rapat sehingga beresiko produk mudah rusak akibat ada udara dari luar yang masuk. Mitra menghendaki perbaikan proses pengemasan dnegan fasilatasi mesin pengemas sistem pedal/injak (pedal sealer). Alat ini telah diberikan kepada mitra dan telah digunakan. Keunggulan alat ini adalah dapat mengemas plastic yang lebih tebal, lebih cepat, efisien, dan praktis.

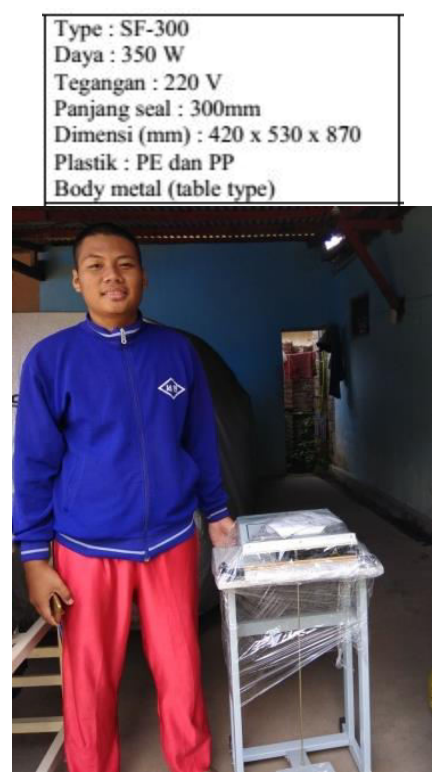

Gambar 8. Pedal sealer

\section{KESIMPULAN}

Program peningkatan kapasitas produksi dan mutu produk olahan di KWT Mekar Jaya dilakukan melalui fasilitasi peralatan produksi sambel pecel dan keripik pangsit berupa penggiling bumbu pecel dan pencetak lembaran adonan (sheeter). Perbaikan kualitas kemasan dilakukan melalui fasilitasi hand sealer dan perbaikan desain label kemasan. Program peningkatan kapasitas produksi dan mutu olahan UKM Ananda dilakukan melalui peningkatan kapasitas pemanggangan, pengadonan, dan perbaikan proses pengemasan. Perbaikan label kemasan akan dilakukan untuk kemasan keripik pangsit, sambel pecel, dan madumongso dengan fasilitasi alat pedal sealer. Dengan adanya fasilitasi peralatan ini, kedua mitra dapat meningkatkan kapasitas dan efisiensi produksi. Mitra juga telah melakukan diversifikasi produk olahannya menggunkan fasilitas peralatan dari program IbM ini. 


\section{DAFTAR PUSTAKA}

Fajriutami, T. 2005. Madumongso sebagai Carrier Food Bakteri Asam Laktat Berpotensi Probiotik. Skripsi. Fateta, IPB. Bogor, 2005

Fuadati, S.R. 2008. Analisis Swot Untuk Pengembangan Potensi Dan Peluang Pasar Kabupaten Blitar Yang Bertumpu Pada Potensi Sumberdaya Alam. EKUITAS (Jurnal Ekonomi dan Keuangan) 12(2): 252-273.

Pemerintah Kabupaten Blitar. www.blitarkab.go.id. Tanggal akses 5 Mei 2016. 